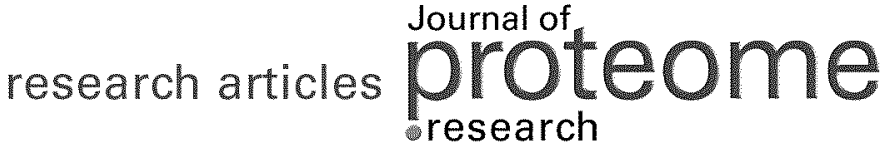

\section{Targeting Therapy for Breast Carcinoma by ATP Synthase Inhibitor Aurovertin B}

\author{
Tsui-Chin Huang, ${ }^{\dagger, \text {, } H s i n-Y i ~ C h a n g, ~}{ }^{\dagger, \Phi}$ Chun-Hua Hsu, ${ }^{\ddagger}$ Wen-Hung Kuo, ${ }^{\S}$ King-Jen Chang, ${ }^{\S}$ and \\ Hsueh-Fen Juan*,t, ${ }^{*, \perp, \#}$
}

\begin{abstract}
Institute of Molecular and Cellular Biology, National Taiwan University, Taipei 106, Taiwan, Department of Agricultural Chemistry, National Taiwan University, Taipei 106, Taiwan, Department of Surgery, National

Taiwan University Hospital and College of Medicine, Taipei 100, Taiwan, Department of Life Science, National Taiwan University, Taipei 106, Taiwan, Institute of Biomedical Electronics and Bioinformatics, National Taiwan University, Taipei 106, Taiwan, and Center for Systems Biology and Bioinformatics, National Taiwan
\end{abstract} University, Taipei 106, Taiwan

\section{Received November 14, 2007}

Targeting of tumor tissues is one of the most powerful approaches to accelerate the efficiency of anticancer treatments. The investigation of effective targets, including proteins specifically and abundantly expressed in abnormal regions, has been one of the most important research topics in cancer therapy. In this study, we performed a proteomic analysis on human breast carcinoma tissues to investigate the tumor-specific protein expression in breast carcinoma. Our study showed that ATP synthase was up-regulated in tumor tissues and was present on the plasma membrane of breast cancer cells. Furthermore, we treated the breast cancer cells with ATP synthase inhibitors and examined the inhibitory efficiency. Aurovertin B, an ATP synthase inhibitor, has strong inhibition on the proliferation of several breast cancer cell lines, but little influence on the normal cell line MCF-10A. Aurovertin B inhibits proliferation of breast cancer cells by inducing apoptosis and arresting cell cycle at the G0/G1 phase. This study showed aurovertin B can be used as an antitumorigenic agent and may be exploited in cancer chemotherapy.

Keywords: targeting therapy $\bullet$ proteomic analysis $\bullet$ ATP synthase $\bullet$ aurovertin B $\bullet$ breast carcinoma $\bullet$ apoptosis • cell cycle arrest

\section{Introduction}

Breast cancer is the most common malignancy among women in developed regions of the world. In the United States, more than 200000 women are diagnosed with breast cancer each year and nearly 41000 patients die of the disease. ${ }^{1}$ In the past decade, the identification of new biomarkers and drug targets has significantly improved breast cancer detection and therapies. ${ }^{2-6}$ The investigation of effective targets, including proteins specifically and abundantly expressed in abnormal regions, has therefore been one of the most important research topics in cancer therapy. The understanding of the roles played in the tumor-specific proteins such as estrogen receptor,

* Address correspondence to: Hsueh-Fen Juan, Ph.D., Department of Life Science, Institute of Molecular and Cellular Biology, National Taiwan University, No 1, Sec. 4, Roosevelt Road, Taipei, 106 Taiwan. Tel: +886-233664536. Fax: +886-2-23673374. E-mail: yukijuan@ntu.edu.tw.

Institute of Molecular and Cellular Biology, National Taiwan University.

ฯ These authors contributed equally to this work.

₹ Department of Agricultural Chemistry, National Taiwan University.

${ }^{\S}$ Department of Surgery, National Taiwan University Hospital and College of Medicine.

${ }^{\triangle}$ Department of Life Science, National Taiwan University.

${ }^{\perp}$ Institute of Biomedical Electronics and Bioinformatics, National Taiwan University.

* Center for Systems Biology and Bioinformatics, National Taiwan University. progesterone receptor, and HER2 receptor has resulted in effective novel systemic therapies. ${ }^{7-11}$

In this study, we performed a proteomic analysis on human breast carcinoma tissues to investigate the tumor-specific protein expression in breast carcinoma. Using two-dimensional electrophoresis (2DE) and MALDI-TOF-MS, we were able to identify a list of upregulated proteins in cancerous tissue which might be promising drug targets. In our study, ATP synthase $\beta$ subunit was found to be expressed at high levels in the tumor tissue. For a long time, F1F0 ATP synthase expression was believed to be found only in mitochondria where most cellular ATP synthesis takes place. ${ }^{12,13}$ However, recent evidence indicate that ATP synthase is expressed on the extracellular surface of endothelial cells in some cancer tissues, but its function with regard to cancer development is still unclear. ${ }^{14-20}$ ATP synthase is the enzyme catalyzing the synthesis of ATP which projects from the inner membrane surface to the mitochondrial matrix. ${ }^{12,13}$ Besides ATP production, recent studies suggest that components of ATP synthase exist on the outer surface of the plasma membrane where they function as receptors for various ligands and are involved in biological processes such as metabolism of lipid formation, regulation of the proliferation and differentiation in endothelial cells, and recognition of immune responses of tumor cells. ${ }^{19,21-25}$ 


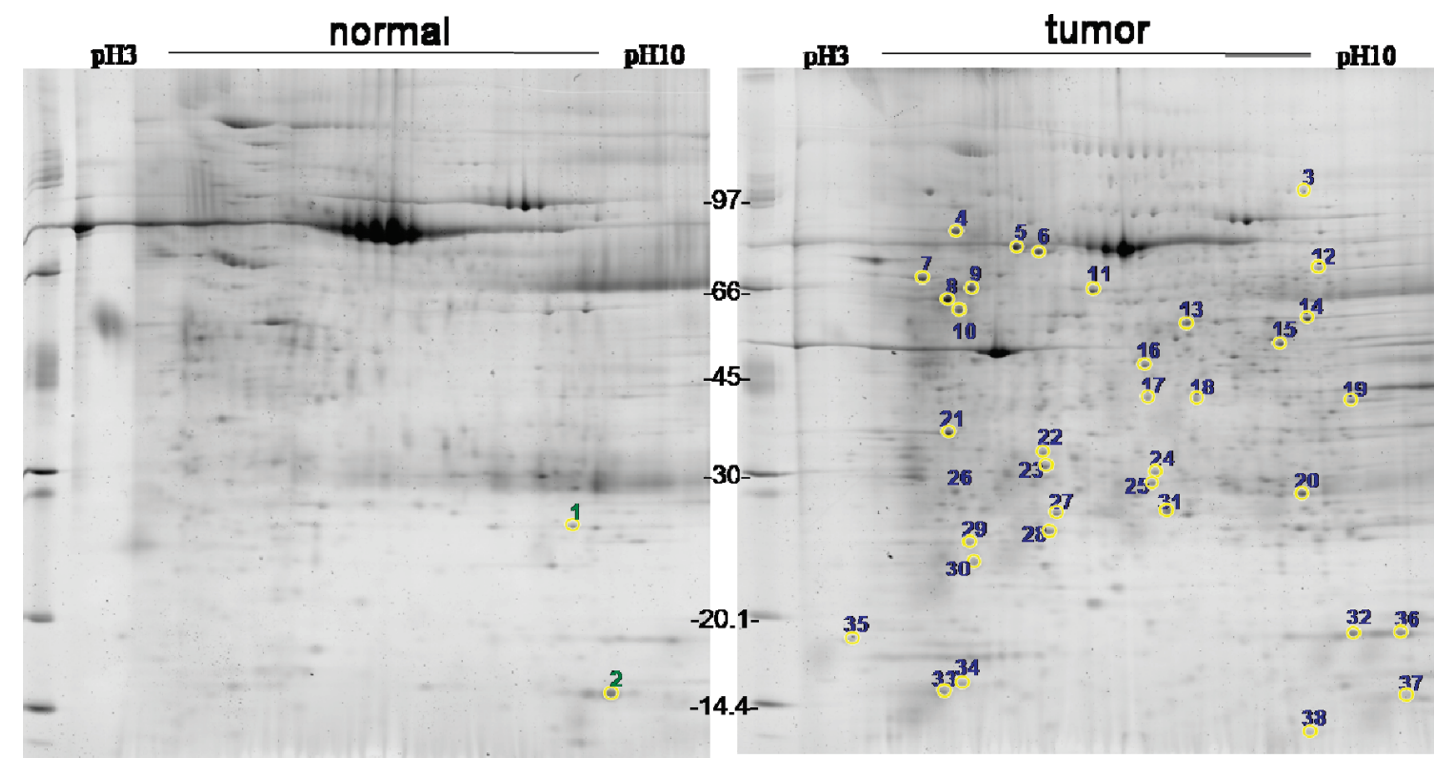

Figure 1. 2DE of human breast tissues and paired tumor-adjacent normal tissues. Protein spots between normal and tumor breast tissues were compared. Proteins indicated in the map were considered differentially expressed and were further identified by MS. Protein identifications are listed in Table 1.

Until now, no investigation has been made to explore the possible therapeutic application of ATP synthase inhibitors in breast cancer treatment. In accordance with previous studies, ATP synthase was observed to be expressed on the extracellular surface of the plasma membrane in our study. Here, we are the first to provide evidence that ATP synthase is a recognition molecule in breast cancer cells and could very possible be a drug target for cancer therapy. We found that, when treated with ATP synthase inhibitor, aurovertin B, breast cancer cells exhibited a significant decrease in cell density. Our data also showed that aurovertin B is able to induce cell death by apoptosis. These results demonstrate that drug targeting could prove to be effective in cancer therapies in the future.

\section{Materials and Methods}

Breast Cancer Specimens and Protein Extraction. Tissue samples were obtained from breast carcinoma patients at different stages that had undergone surgical resection at National Taiwan University Hospital, Taipei, Taiwan. The breast cancer tissue of the patients and the adjacent normal tissue were collected. The frozen tissue was lyophilized and grinded into powder with liquid $\mathrm{N}_{2}$ and stored at $-80^{\circ} \mathrm{C}$ until use. The powdered tissue was dissolved in $1 \mathrm{~mL}$ of lysis solution containing $7 \mathrm{M}$ urea (Boehringer, Mannheim, Germany), $2 \mathrm{M}$ thiourea, 4\% CHAPS (J. T. Baker, Phillipsburg, NJ), and $0.002 \%$ bromophenol blue (Amersco, OH). The mixture was discontinuously and manually sonicated for $5 \mathrm{~min}$ on ice. The extracted protein concentration was measured with a protein assay kit (Bio-Rad, Hercules, CA).

Two-Dimensional Gel Electrophoresis (2DE). 2DE was performed using Ettan IPGphor II (Amersham Pharmacia Biotech, Uppsala, Sweden) as previously described. ${ }^{26}$ Total proteins $(500 \mu \mathrm{g})$ were mixed with rehydration buffer containing $7 \mathrm{M}$ urea (Boehringer), $2 \mathrm{M}$ thiourea, 4\% CHAPS (J. T. Baker), 65 mM DTE, 0.5\% pH 3-10 NL IPG Buffer, and 0.002\% bromophenol blue (Amersco) to a total volume of $350 \mu \mathrm{L}$. The mixtures were loaded onto an $18 \mathrm{~cm} \mathrm{pH} \mathrm{3-11} \mathrm{NL} \mathrm{gradient}$ Immobiline DryStrip (Amersham Pharmacia Biotech). IEF parameters for separation were $50 \mu \mathrm{A}$ /strip at $20{ }^{\circ} \mathrm{C}$ with a rehydration step for $12 \mathrm{~h}$. IEF was carried out using the following conditions: (1) $100 \mathrm{~V}$ for $1 \mathrm{~h}$; (2) $250 \mathrm{~V}$ for $1 \mathrm{~h}$; (3)500 $\mathrm{V}$ for $1 \mathrm{~h}$; (4) $1000 \mathrm{~V}$ for $1 \mathrm{~h}$; (5) $4000 \mathrm{~V}$ for $1 \mathrm{~h}$; and (6) $8000 \mathrm{~V}$ for $85000 \mathrm{Vh}$. After reduction with $65 \mathrm{mM}$ DTE and alkylation with $55 \mathrm{mM}$ iodoacetamide, the second-dimensional separation was performed on a linear gradient $10-18 \%$ polyacrylamide gel. The protein gels were fixed in $10 \%$ methanol/7\% acetic acid and stained using the SYPRO Ruby method (Invitrogen Corporation, Carlsbad, CA). Gels were then scanned using a Typhoon 9200 Fluorescence Imager (Amersham Pharmacia Biotech) and analyzed using the Image Master 2D elite software package (Amersham Pharmacia Biotech) with high image quality TIF format.

In-Gel Digestion and Protein Identification. By gel-to-gel comparison, the 2D image of the tumor tissue was set as the reference gel image. After matching the normal tissue gel image to the reference image, only the protein spots displayed on the tumor tissue gel were excised. The gel pieces were washed with 1:1 (v/v) solution containing $50 \mathrm{mM}$ ammonium bicarbonate and acetonitrile (ACN). After treatment with $\mathrm{Na}_{2} \mathrm{CO}_{3}$, proteins were digested for $16 \mathrm{~h}$ at $37^{\circ} \mathrm{C}$ with sequence-grade trypsin (Promega Corporation, WI). The resulting peptides were extracted from the gel with $1 \%$ trifluoroacetic acid (TFA) in 50\% ACN. The combined extracts were evaporated to drynes, and the protein fragments were dissolved in $0.1 \%$ TFA in $2 \% \mathrm{ACN}$ and directly spotted onto the sample plate of a MALDI-TOF mass spectrometer.

MALDI-TOF MS or MS/MS were performed on a dedicated Q-Tof Ultima MALDI instrument (Micromass, Manchester, U.K.) with fully automated data directed acquisition using predefined probe motion pattern and peak intensity threshold for switching over from MS survey scan to MS/MS, and from one MS/MS to another. All individual MS/MS data thus generated from a particular sample well were then output as a single MASCOT-searchable peak list file. Within each sample well, parent ions that met the predefined criteria (any peak within the $m / z$ 80-3000 range with intensity above 10 count \pm include/ exclude list) were selected for CID MS/MS using argon as the collision gas and a mass dependent $\pm 5 \mathrm{~V}$ rolling collision 
Table 1. List of Identified Proteins with Significant Differential Expression in Cancerous Tissues

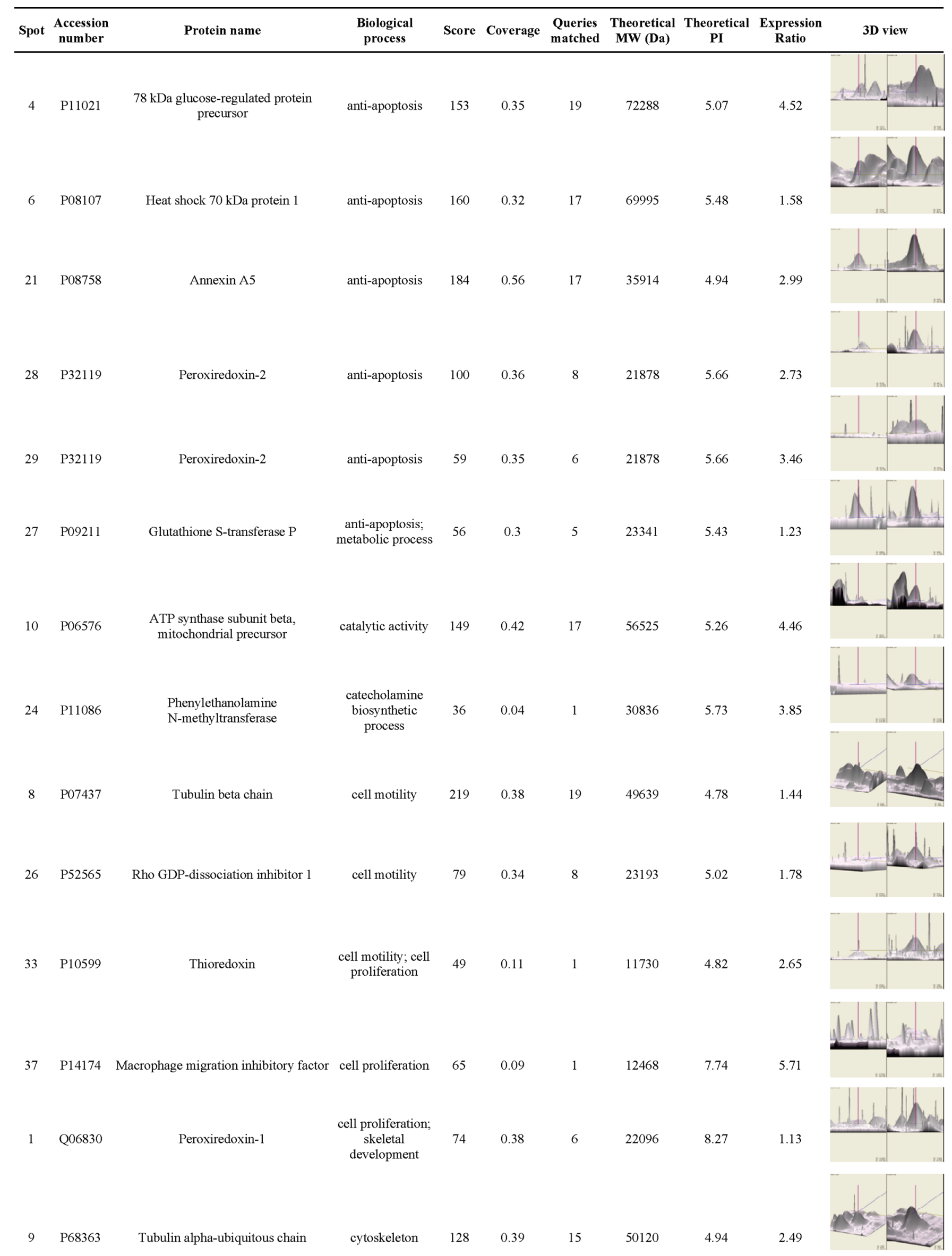


Table 1. Continued

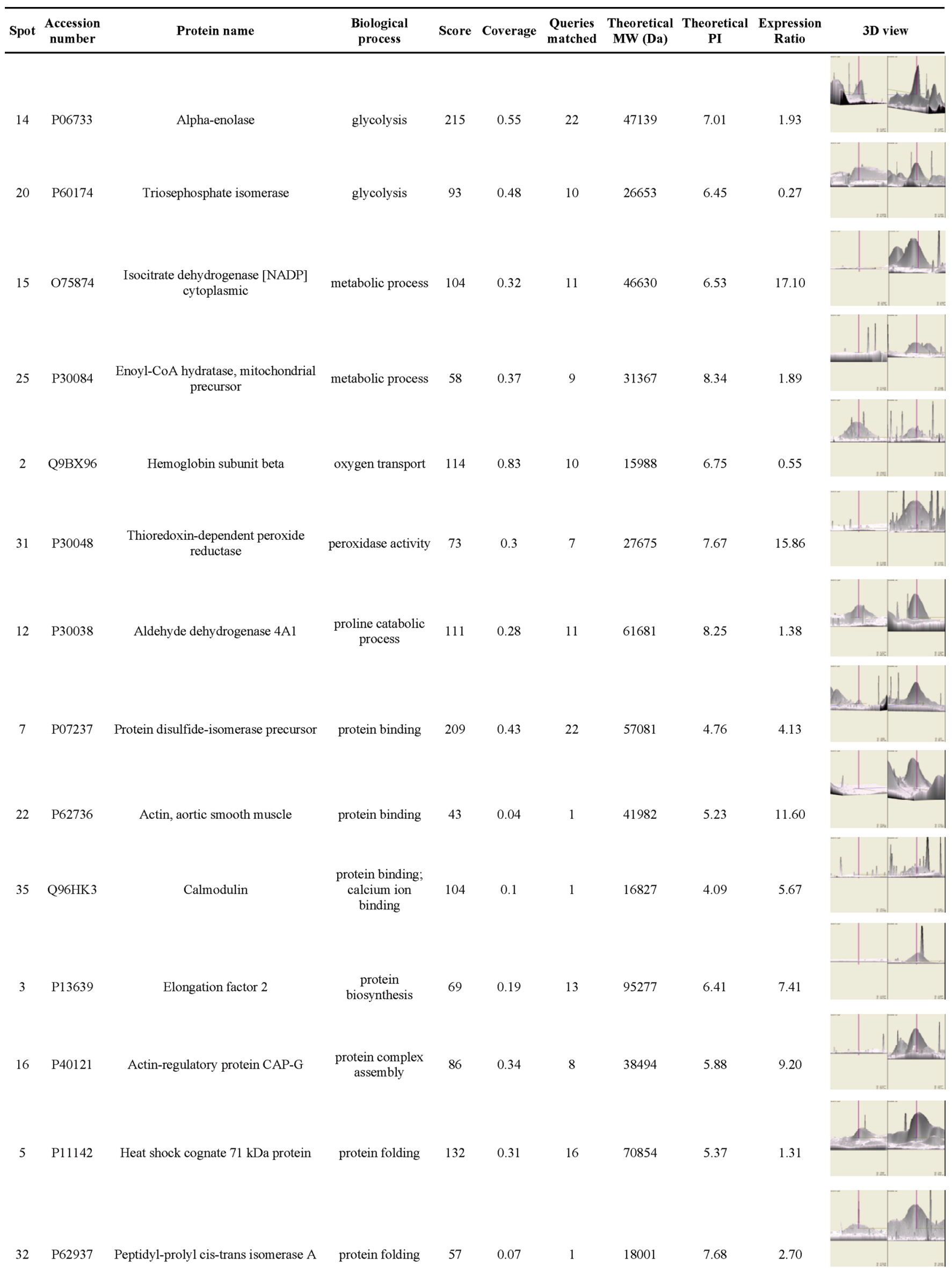


Table 1. Continued

\begin{tabular}{|c|c|c|c|c|c|c|c|c|c|c|}
\hline Spot & $\begin{array}{c}\text { Accession } \\
\text { number }\end{array}$ & Protein name & $\begin{array}{l}\text { Biological } \\
\text { process }\end{array}$ & Score & Coverage & $\begin{array}{l}\text { Queries } \\
\text { matched }\end{array}$ & $\begin{array}{l}\text { Theoretical } \\
\text { MW (Da) }\end{array}$ & $\begin{array}{l}\text { Theoretical } \\
\text { PI }\end{array}$ & $\begin{array}{l}\text { Expression } \\
\text { Ratio }\end{array}$ & 3D view \\
\hline 36 & P62937 & Peptidyl-prolyl cis-trans isomerase A & protein folding & 58 & 0.42 & 6 & 18001 & 7.68 & 25.72 & \\
\hline 38 & Q91888 & Ubiquitin & $\begin{array}{l}\text { protein } \\
\text { ubiquitination }\end{array}$ & 108 & 0.72 & 8 & 8560 & 6.56 & 6.16 & \\
\hline 34 & P09382 & Galectin-1 & $\begin{array}{l}\text { regulation of } \\
\text { apoptosis }\end{array}$ & 84 & 0.55 & 7 & 14706 & 5.34 & 1.74 & \\
\hline 11 & P30101 & $\begin{array}{c}\text { Protein disulfide-isomerase A3 } \\
\text { precursor }\end{array}$ & signal transduction & 117 & 0.27 & 13 & 56747 & 5.98 & 9.65 & \\
\hline 13 & P50395 & Rab GDP dissociation inhibitor beta & signal transduction & 128 & 0.47 & 16 & 50631 & 6.11 & 2.84 & \\
\hline 23 & P35232 & Prohibitin & signal transduction & 87 & 0.44 & 8 & 29786 & 5.57 & 1.34 & \\
\hline 19 & P07355 & Annexin A2 & $\begin{array}{c}\text { skeletal } \\
\text { development }\end{array}$ & 102 & 0.37 & 12 & 38580 & 7.57 & 18.02 & \\
\hline 17 & P05388 & $60 \mathrm{~S}$ acidic ribosomal protein $\mathrm{P} 0$ & translation & 57 & 0.21 & 6 & 34252 & 5.71 & 7.97 & \\
\hline 18 & P05388 & $60 \mathrm{~S}$ acidic ribosomal protein $\mathrm{P} 0$ & translation & 85 & 0.25 & 8 & 34252 & 5.71 & 12.93 & \\
\hline 30 & O75223 & Uncharacterized protein C7orf 24 & unknown & 67 & 0.57 & 6 & 20994 & 5.07 & 6.41 & \\
\hline
\end{tabular}

energy until the end of the probe pattern was reached (all details are available at http://proteome.sinica.edu.tw). Subsequently, protein identification was determined by searching in the Swiss-Prot version 51.7 database using the MASCOT (http:// www.matrixscience.com) search engine as previously described. ${ }^{26}$ All the searching parameters were set as follows: peptide mass tolerance was $\pm 50 \mathrm{ppm}$; fragment mass tolerance was $\pm 0.25 \mathrm{Da}$; only tryptic peptides with up to one missed cleavage site were allowed; modifications were carbamidomethylation (C) and oxidation of methionine. For positive identification, the score of the result of $[-10 \log (P)]$ had to be over the significance threshold level $(P<0.05)$.

Homology Modeling. The three-dimensional model of ATP synthase was generated with the MODELER program encoded in InsightII (Accelrys, Inc., CA) using bovine ATP synthase (Protein Data Bank code 1H8E) as the template structure. MODELER uses a spatial restraint method to build up a 3-D image of the protein structure. MODELER is capable of generating a reliable predicted structure using probability density functions derived from homologous structures and general features of known proteins. ${ }^{27}$ For ATP synthase protein alignment, MODELER yielded only one model with high similarity to the bovine template. The coordinates of the highresolution structure of bovine ATP synthase were used to model the main chain conformation of human ATP synthase. The structure with the lowest violation score and lowest energy score was chosen as the candidate.

Docking Simulation. To further explore possible interaction of drug candidates with ATP synthase, a docking experiment was performed using the receptor molecular model and docking protocol as previously described. ${ }^{28}$ This protocol consists in the flexible fitting of ligand (Aurovertin B, resveratrol and picetanol) within a rigid receptor (ATP synthase, homologues to PDB entry $1 \mathrm{H} 8 \mathrm{E})^{29}$ using the shape-based docking algorithm 


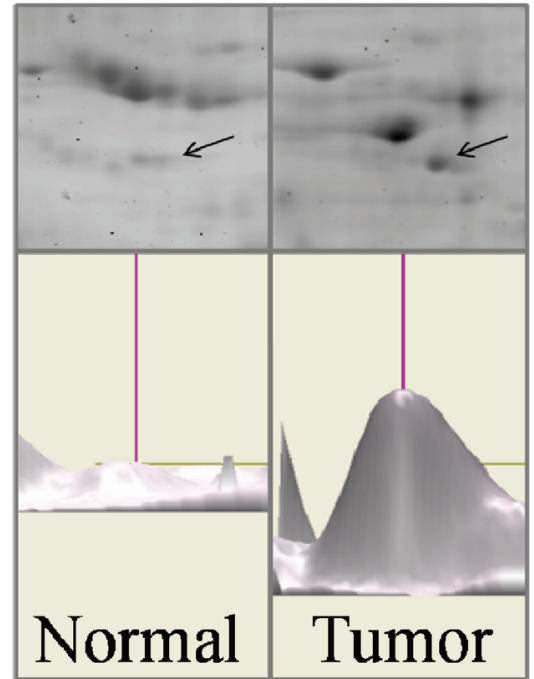

Figure 2. The $2 \mathrm{D}$ and $3 \mathrm{D}$ view of ATP synthase $\beta$ subunit expression profile. The expression of ATP synthase $\beta$ subunit was highly increased in cancer tissues. Arrows indicate ATP synthase $\beta$ subunit.

LigandFit. ${ }^{30}$ The obtained poses were subsequently scored using the LigScore scoring function. ${ }^{31}$ The best pose was then energy minimized with CHARMm ${ }^{32}$ allowing full flexibility for the ligand and only side-chain flexibility for the receptor. All calculations were carried out in the Discovery Studio 1.2 environment (Accelrys, Inc.) as previously described. ${ }^{33}$

Cell Culture. Human breast cancer cell lines, MCF-7, MDAMB231, and T47D, and human normal breast cell line MCF10A, were obtained from the American Type Culture Collection (Manassas, VA). Human breast cancer cell lines were maintained in DMEM at $37{ }^{\circ} \mathrm{C}$ with $5 \% \mathrm{CO}_{2}$ (Gibco, Carlsbad, CA), $5 \%$ fetal bovine serum (Gibco), 50 units $/ \mathrm{mL}$ penicillin, and 50 $\mu \mathrm{g} / \mathrm{mL}$ streptomycin (Gibco). MCF-10A cells were cultured in DMEM (Gibco), $0.01 \mathrm{mg} / \mathrm{mL}$ insulin, and $5 \mu \mathrm{g} / \mathrm{mL}$ hydrocortisone.
Flow Cytometry. Cells were harvested,washed with PBS, and incubated with monoclonal anti- $\beta$-subunit antibody (Abcam, Cambridge, U.K.) (1:500) for $30 \mathrm{~min}$. Cells were then washed twice with PBS and incubated with a secondary goat antimouse antibody-FITC (Chemicon Inc., MA) in the dark for 30 min. All antibody incubations were carried out at $4{ }^{\circ} \mathrm{C}$ in PBS with $1 \%$ BSA. The mean fluorescent intensity of FITC in 10000 cells was quantified by FACSCalibur flow cytometer (Becton Dickinson, Franklin Lakes, NJ).

Confocal Microscopy. Cells were plated at 150000 cells $/ \mathrm{mL}$ on glass coverslips and allowed to adhere overnight. Cells were fixed in $4 \%$ paraformaldehyde solution at room temperature. A control slide was permeabilized in $1 \%$ Triton X-100 for 30 $\mathrm{min}$ at room temperature after fixation. All coverslips were incubated in $0.1 \%$ BSA in Dulbecco's PBS overnight at $4{ }^{\circ} \mathrm{C}$ and washed before incubation with monoclonal anti- $\beta$-subunit antibody (Abcam) (1:250) for $1 \mathrm{~h}$. All cells were washed three times and incubated for $30 \mathrm{~min}$ in the dark at room temperature with a secondary goat anti-mouse antibody-PE (1:100). After the final washes, cells were visualized using a Zeiss LSM510 (Switzerland) confocal microscope.

MTT Assay. Cytotoxic effects on the growth and viability of cells were determined using MTT (3(4,5-dimethylthiazol-2-yl)2,5-diphenyltetrazolium bromide, a tetrazole) assay. Cells $\left(10^{4}\right.$ cells $/ \mathrm{mL}$ ) were plated in 96-well plates and allowed to attach for $24 \mathrm{~h}$. Cells were treated with $0.1-10 \mu \mathrm{m}$ of aurovertin B, resveratrol, and piceatannol for $48 \mathrm{~h}$. At the end of the incubation period, MTT reagent $(10 \mu \mathrm{L})$ was added to each 100 $\mu \mathrm{L}$ of culture. After incubation for $4 \mathrm{~h}$ at $37^{\circ} \mathrm{C}$, the formed water insoluble formazan dye was solubilized by adding $100 \mu \mathrm{L}$ of DMSO to the culture wells. The plates were further incubated for $15 \mathrm{~min}$ at room temperature, and optical density (OD) of the wells was determined using ELISA microplate reader at a test wavelength of $570 \mathrm{~nm}$. All experiments were performed in triplicates.

Cell Cycle Analysis. For the determination of cell cycle phase distribution, $3 \times 10^{5}$ MCF-7 cells were first exposed to various
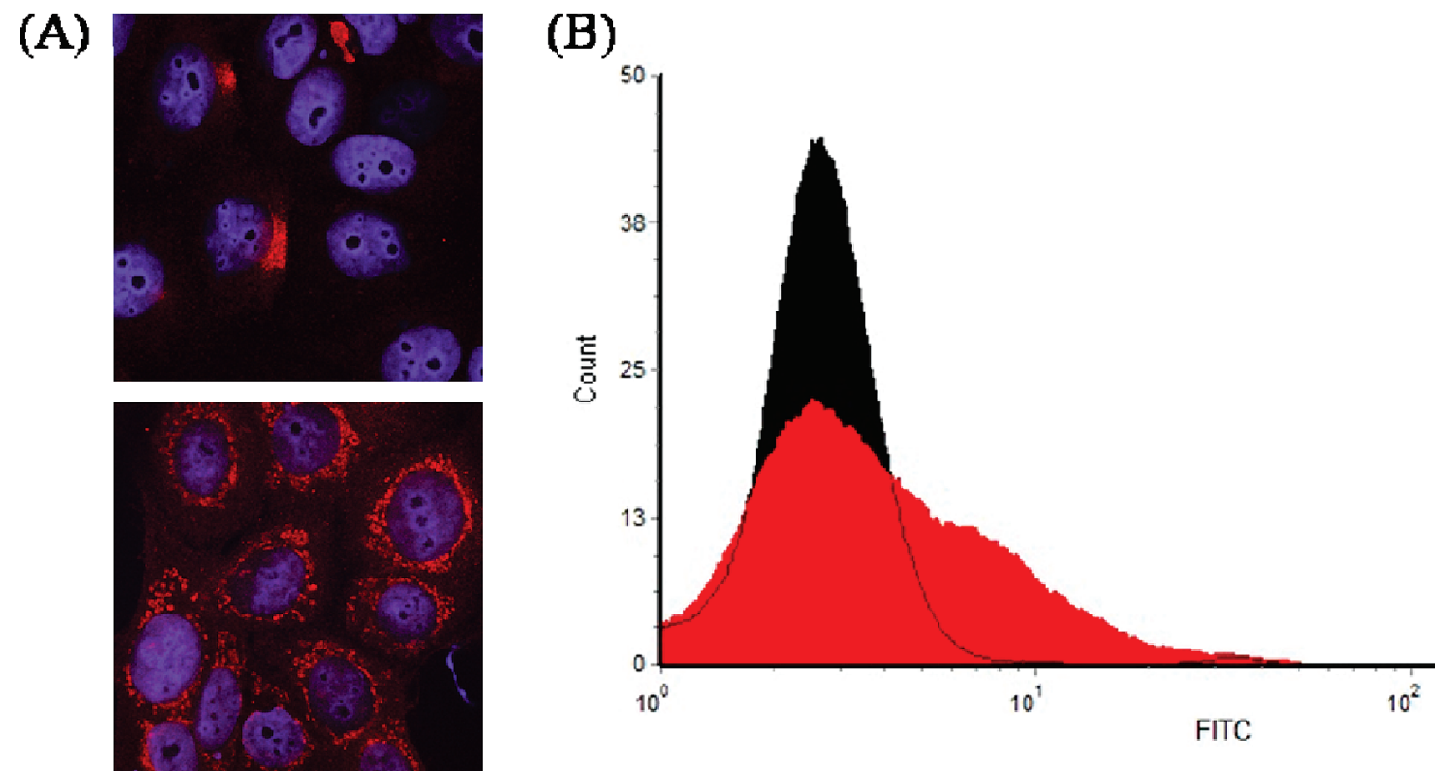

Figure 3. Characterization of ATP synthase expressed on MCF-7 cell surface. (A) Confocal microscopy image of the distribution of ATP synthase $\beta$ subunit on MCF-7 cell surface. MCF-7 were fix and with (lower)/without (upper) permeabilization. Red, ATP synthase $\beta$ subunit; blue, hoechst 33342. (B) FACS analyzed MCF-7 cells expressing ATP synthase $\beta$ subunit. Cells in red area represent the ones stained with anti-ATP synthase $\beta$ subunit Ab followed by FITC-labeled anti-mouse IgG antibodies. Cells in black area denote negative control cells. 


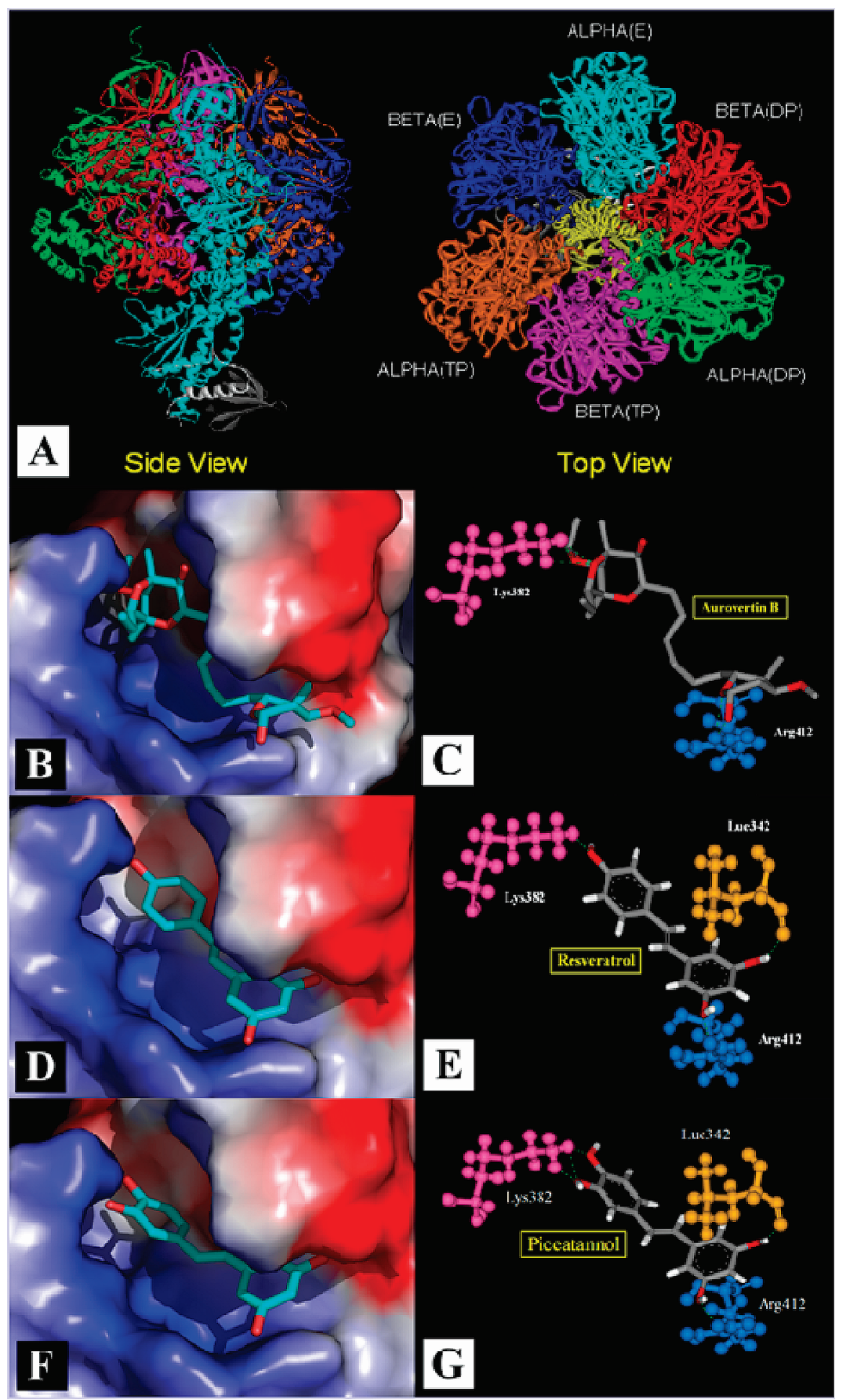

Figure 4. Homology modeling of human ATP synthase and the binding mode of three inhibitors to ATP synthase. (A) Homology modeling of human ATP synthase F1 subunit. The different chains are represented in various colors. This model was used to serve as the target protein for docking simulation to estimate the drug affinity with human ATP synthase. (B) Aurovertin B, (D) resveratrol, and (F) piceatannol were docked into the ATP synthase $\beta$ subunit catalytic site. Hydrophobic (white), negatively charged (red), and positively charged (blue) regions are shown. The 3-D pictures were obtained using Discovery Studio 1.2. (C) Aurovertin B, (E) resveratrol, and (G) piceatannol molecules are shown to form hydrogen bonds with ATP synthase $\beta$ subunit. The 3-D pictures were obtained using PyMol. ${ }^{50}$

concentrations of aurovertin B in DMEM with 10\% FBS for $48 \mathrm{~h}$ using flow cytometry. The cells were trypsinized, collected, and fixed in $70 \%$ cold ethanol $\left(-20^{\circ} \mathrm{C}\right)$ overnight. After washing twice with PBS, cells were resuspended in PBS. RNase A (1 mg/ $\mathrm{mL})$ and PI $(10 \mu \mathrm{g} / \mathrm{mL})$ were added to the fixed cells for 30 min. The DNA content of cells was then analyzed with a
FACSCanto instrument (Becton Dickinson, San Jose, CA). The percentage of cells in different phases of the cell cycle was calculated by MultiCycle (DeNovo software, Ontario, Canada).

Annexin V-FITC/PI Analysis. Flow cytometric analysis was performed to identify and quantify the apoptotic cells using Annexin V-FITC/PI (propidium iodide) apoptosis detection kit 


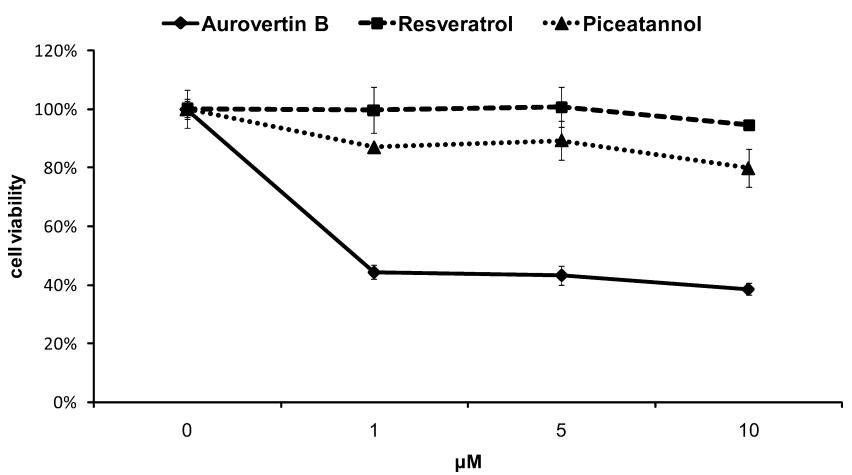

Figure 5. Effects of ATP synthase inhibitors on cell viability in MCF-7 breast cancer cells. MTT assay was performed to characterize the specificity of ATP synthase inhibitors on tumor cells. MCF-7 cells were treated with three chemicals, separately, for $48 \mathrm{~h}$. Aurovertin B caused significant cytolysis in MCF-7. On the other hand, cells treated with the other two ATP synthase inhibitors (resveratol and piceatannol) had $80 \%$ and higher cell viability rate at the same concentrations and the same time points compared with aurovertin B.

(Santa Cruz Biotechnology, Santa Cruz, CA). Cells were treated with $0.1-10 \mu \mathrm{m}$ of aurovertin B for $48 \mathrm{~h}$. After incubation, floating and adherent cells were harvested. Cells were washed carefully with cold PBS at $4{ }^{\circ} \mathrm{C}$. Cell pellets were resuspended in $100 \mu \mathrm{L}$ of binding buffer. Annexin-V FITC $(0.2 \mu \mathrm{g} / 100 \mu \mathrm{L})$ and PI $(10 \mu \mathrm{g} / \mathrm{mL})$ were added to the cells and left to incubate in the dark for $15 \mathrm{~min}$ at room temperature. All data were acquired using flow cytometry with a FACSCanto cytometer (Becton Dickinson, San Jose, CA). The flow cytometric analysis was performed using FCS Express 3.0 (DeNovo software).

DAPI Staining. After treatment for $48 \mathrm{~h}$ with DMSO (control) or aurovertin $\mathrm{B}$ (at their respective $\mathrm{IC}_{50}$ concentrations), cells were fixed in $4 \%$ paraformaldehyde for $15 \mathrm{~min}$ and stained with DAPI ( $2 \mu \mathrm{g} / \mathrm{mL}$ in PBS) for $15 \mathrm{~min}$ at $37^{\circ} \mathrm{C}$ to detect apoptotic bodies (Sigma, St. Louis, MO). Results were determined by visual observation of nuclear morphology via fluorescence microscopy.

Statistical Analysis. The results are presented as means \pm $\mathrm{SD}$ of at least three independent experiments.

\section{Results}

Identification of Potential Target. Proteins extracted from the same patient tissue section were separated using 2DE. Approximately 1000 protein spots were visualized by staining with Sypro Ruby (Figure 1). Differentially expressed protein spots were excised, in-gel digested, and analyzed using MALDI Q/TOF. After database searching, 38 distinct proteins were identified; the results are listed in Table 1. From the results, proteins involved in antiapoptosis, cell motility, cell proliferation, glycolysis, protein folding, signal transduction, and other processes related to tumorgenesis were found to be overexpressed in cancer tissues. Among them, significant upregulation of ATP synthase $\beta$ subunit was observed in breast carcinoma tissue (Figure 2).

$\beta$-Subunits of ATP Synthase Localized on the Surface of MCF-7 Cells. We demonstrated that the $\beta$-subunits of ATP synthase are localized on human breast cell surface by using confocal microscopy with a mAb specific for the $\beta$-subunit of ATP synthase. Each cell displayed one or more irregular clusters of punctuated structures, suggesting an organized distribution of the $\beta$-subunits of ATP synthase on the cell surface. Perme- abilized cells (Figure 3A) produced a considerably different pattern characteristic of mitochondrial staining of ATP synthase. The localization of $\beta$ subunit ATP synthase on human breast cell surface was also confirmed by flow cytometry (Figure 3B).

ATP Synthase Homology Modeling and Docking Simulation. An optimal sequence alignment is essential to the success of homology modeling. The sequence identity between human and bovine ATP synthase is $99 \%$ (data not shown), making this sequence alignment relatively straightforward. After energy minimization, the modeled structure shown in Figure 4A was exhibited as a reliable protein structure prediction. Using this structure, we performed docking simulations for three ligands: aurovertin B (Figure 4B,C), resveratrol (Figure 4D,E), and piceatannol (Figure 4F,G), respectively. These three compounds demonstrated high affinity and formed hydrogen bonds with the Lys382, Arg412, and Lue342 residues of the ATP synthase $\beta$ subunit. The docking results showed a firm binding affinity of aurovertin B to ATP synthase (Aurovertin B = 79.803, Resveratrol $=35.889$, Piceatannol $=44.364$ ). Aurovertin B can dock into ATP synthase $\beta$ subunit. Arg-412 makes an important hydrogen bond interaction with the carbonyl group on the substituted pyrone ring of aurovertin B, and Tyr-458 forms a crucial staggered stacking interaction with the pyrone ring.

Proliferation Inhibition of MCF-7 by $\mathrm{H}^{+}$-ATP Synthase Inhibitors. We performed a cell proliferation assay in the presence of $\mathrm{F}_{1}$-targeting $\mathrm{H}$-ATP synthase inhibitors. As shown in Figure 5, aurovertin B inhibited the growth of MCF-7 cells in a dose-dependent manner. Aurovertin B was the most potent of the inhibitors with an $\mathrm{IC}_{50}$ value at $0.1 \mu \mathrm{M}$. Resveratrol and piceatannol were slightly less effective than aurovertin B.

Cytotoxicity of Aurovertin B to Breast Cells. To examine the selective cytotoxicity of aurovertin B to cancer cells, we conducted MTT assay to measure the cell viability of breast cancer cell lines T47D, MDAMB231, and MCF-7, as well as normal breast cell line MCF-10A (Figure 6). The $\mathrm{IC}_{50}$ values of T47D, MDAMB231, and MCF-7 were 0.89, 5.52, and $0.09 \mu \mathrm{M}$, respectively, after aurovertin B treatment for $48 \mathrm{~h}$. The results showed no apparent cytotoxicity to normal human breast cell line MCF-10A under these concentrations.

Aurovertin B Inhibits MCF-7 Tumor Cell Growth by Arresting Cell Cycle at the G0/G1 Phase. To investigate the effect of aurovertin B on cell-cycle progression of MCF-7 cells, their DNA content was analyzed by flow cytometry, and the derived data was used to investigate the phase distribution of the cell cycle. As shown in Figure 7, the investigated MCF-7 cells revealed a cell-cycle distribution typical of that in rapidly proliferating cells, with $63.1 \%$ of cells featuring a $2 n$ DNA content, corresponding to the G0/G1-phase, $11.6 \%$ of cells exhibiting a $4 n$ DNA content (G2/M), and $25.3 \%$ with a DNA content between $2 n$ and $4 n$, corresponding to the S-phase. In aurovertin B treated cells, percentage of G0/G1 phase was increased from $63.1 \%$ to $66.5 \%, 78.5 \%$, and $81.2 \%$ under the respective concentrations in a dose-dependent manner.

Aurovertin B Induced Apoptosis in Human MCF-7 Cells. To clarify whether the induced decrease in viability and growth rate was attributable to apoptosis, pattern characteristics of apoptosis were investigated by FITC-annexin V and PI staining (Figure 8) and DAPI staining. FITC-annexin V and PI staining assay divides apoptotic cells into two stages: early (Annexin $\mathrm{V}^{+} / \mathrm{PI}^{-}$) and late apoptotic/necrotic (Annexin $\mathrm{V}^{+} / \mathrm{PI}^{+}$). As shown in Figure 8, treatment of cells with aurovertin B (0.05-10 


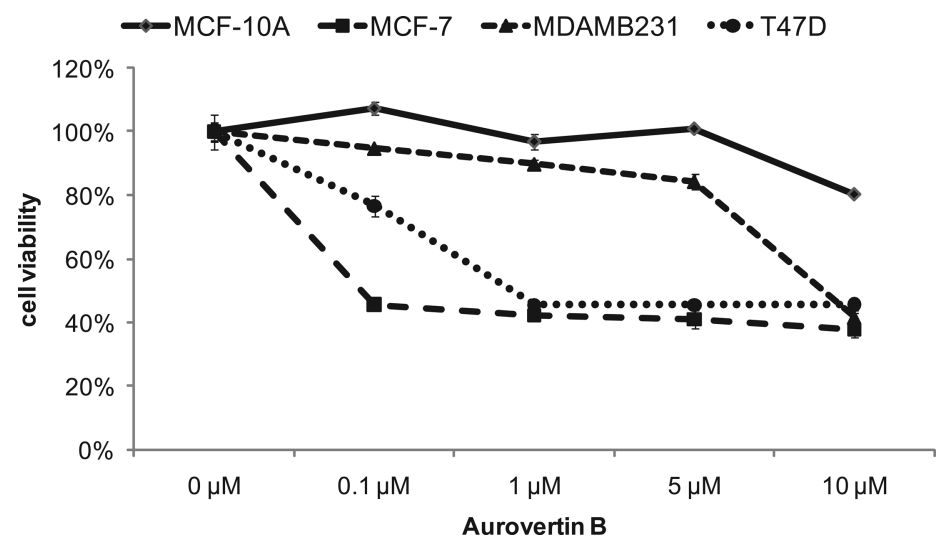

Figure 6. Effects of aurovertin B on cell viability in breast normal cells (MCF-10A) and cancer cells in vitro. MTT assay was performed to characterize the specificity of aurovertin B on tumor cells (MCF-7, MBAMD231, and T47D). Aurovertin B caused significant cytolysis in breast cancer cell lines. However, normal beast cell line MCF-10A cells treated with aurovertin B had $80 \%$ or higher cell viability rate at the same time points, meaning it exerts little toxicity to normal cells.

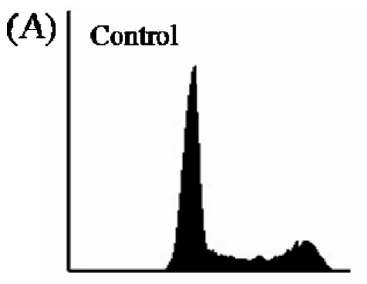

G0/G1 S G2M

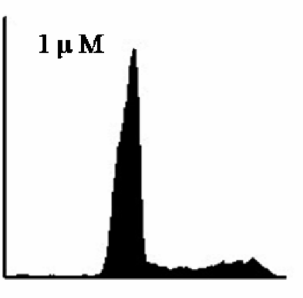

CNG1 S C2M

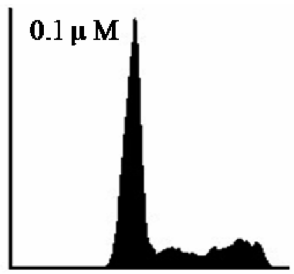

G0/G1 S G2/M

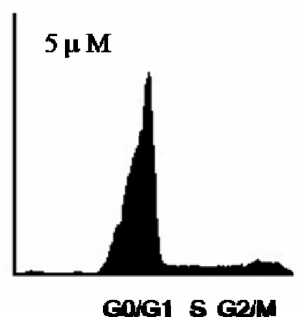

(B)

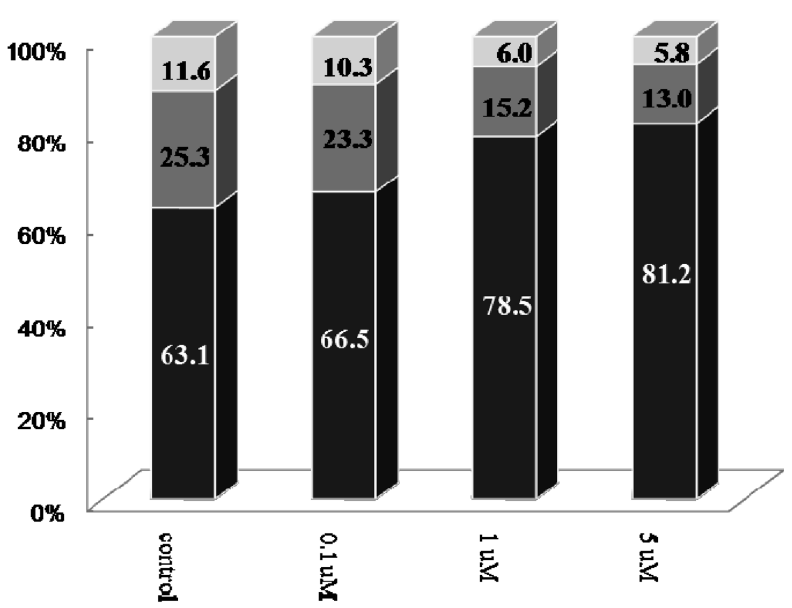

Figure 7. Aurovertin B induces cell cycle arrest. (A) Cell cycle analysis of MCF-7 cells treated with $0.1,1$, and $5 \mu \mathrm{M}$ aurovertin B for $48 \mathrm{~h}$ was performed by flow cytometry. (B) The percentage of cells in the G0/G1, S, and G2/M phase was calculated. MCF-7 cells cultured in the medium without aurovertin B for $48 \mathrm{~h}$ served as the control. In aurovertin B treated cells, percentage of cells in G0/G1 phase was changed from $63.1 \%$ to $66.5 \%, 78.5 \%$, and $81.2 \%$ at $0,0.1,1$, and $5 \mu \mathrm{M}$ concentrations, respectively.

$\mu \mathrm{M})$ resulted in a dose-dependent increase in both early and late apoptotic/necrotic cells. The morphological changes of the nuclei in cells treated with aurovertin B were examined by nuclear staining. As shown in Figure 9, typical apoptotic nuclear changes, such as condensation and shrinkage of nuclei, were observed in MCF-7 cells exposed to aurovertin B.

\section{Discussion}

Proteomic investigation of a given cell type or biological system has been widely practiced since the introduction of mass spectrometry and other methods such as two-dimensional gel electrophoresis and isotope-coded affinity tagging technology. ${ }^{34-37}$ As a result, the screening for disease markers became one of the main topics in a large number of proteomic studies in the past decade. ${ }^{38-42}$

In this study, we performed a proteomic analysis to investigate tumor-specific protein expression of human breast carcinoma tissues. Our results showed that proteins involved in antiapoptosis, cell motility, cell proliferation, glycolysis, protein folding, signal transduction, and other processes related to tumorigenesis were overexpressed in cancer tissues. Among them, we observed significant up- regulation of ATP synthase $\beta$ subunit in breast carcinoma tissue, which suggests that it might play a critical role as a target protein in cancer therapies.

In the past decade, ATP synthase was known to be a membrane-bound protein located on the inner membrane of mitochondria. However, recent studies showed that ATP synthase is expressed on the surface of endothelial cells in cancer tissues, but its functions in cancer progression are still unclear. Our results showed that ATP synthase is in fact expressed on the plasma membrane of cancer cells. With this in mind, we predicted the binding affinity of three ATP synthase F1 subunit inhibitors using structural bioinformatics approaches and found aurovertin B to be a potential anticancer agent. Aurovertin B belongs to the aurovertin family which exhibits toxic property and is a metabolite isolated from the fungus Calcarisporium arbuscula. Known as an ATP synthase inhibitor, aurovertin B acts to prevent the attainment of the tight conformation in the ATPase cycle. ${ }^{29,43}$

Structural bioinformatics involves processes that could determine a protein's three-dimensional structure. Once a homologue of known structure is identified, protein stereo folding can be constructed by structural modeling. MODELER ${ }^{27}$ 

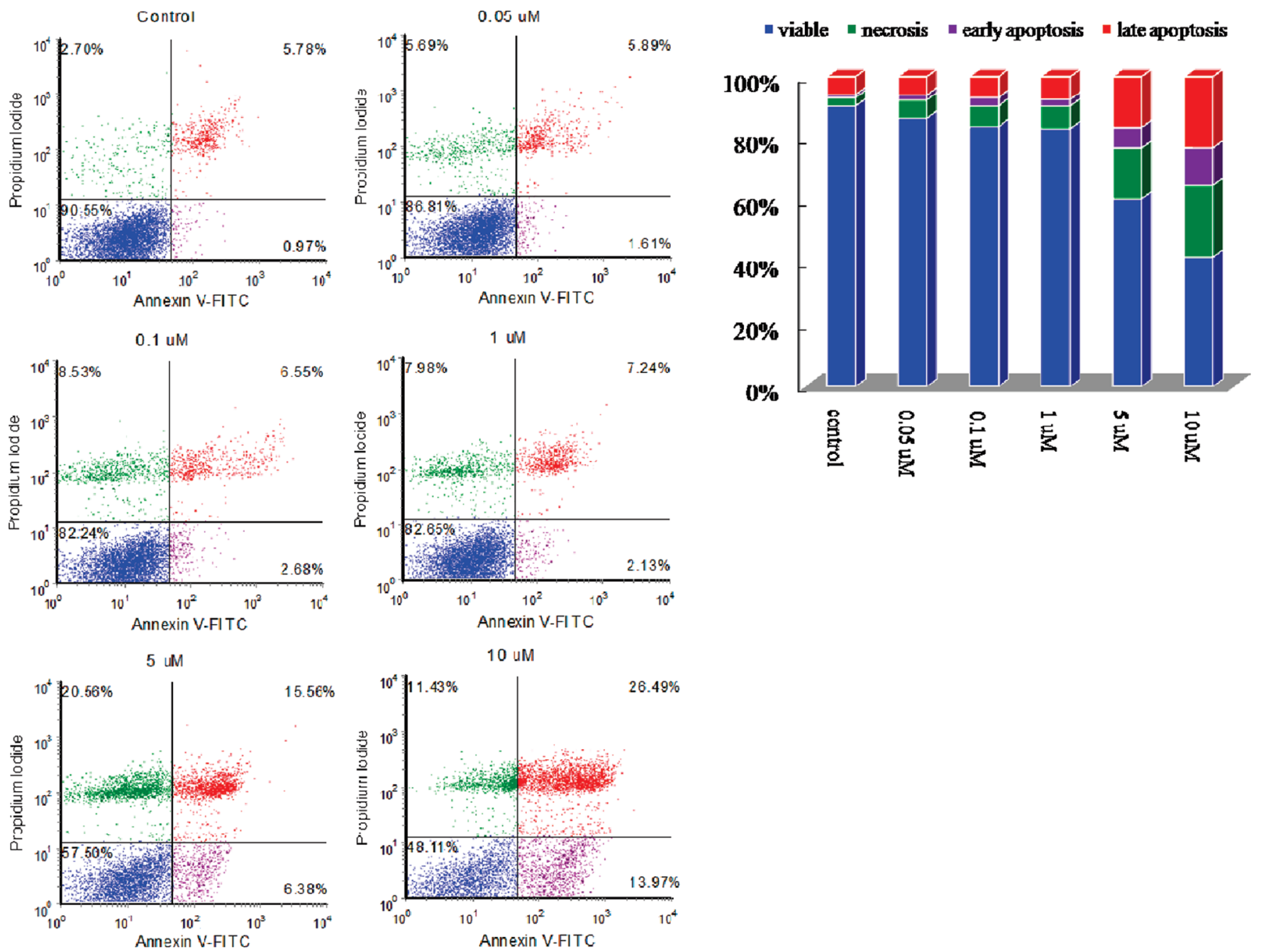

Figure 8. Aurovertin B induces apoptosis of MCF-7. (A) Cells treated with $0.05,0.1,1,5$, and $10 \mu \mathrm{M}$ aurovertin B for $48 \mathrm{~h}$ were doublestained with annexin-V-FITC and propidium iodide (PI) and analyzed by flow cytometry. Lower left quadrant shows viable cells; lower right, Annexin-V positive cells (early apoptosis); upper left, cell positive for PI (necrosis); upper right, cell positive for both Annexin-V and PI (late apoptosis). (B) The percentage of cells in the four quadrants was calculated. MCF-7 cells cultured in the medium without aurovertin $\mathrm{B}$ for $48 \mathrm{~h}$ served as the control.
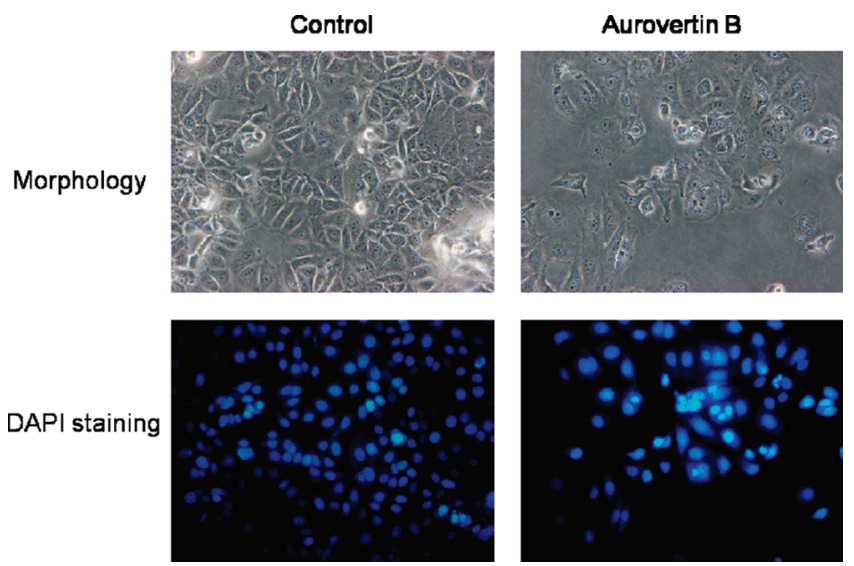

Figure 9. Characterization of aurovertin B induced cell death in human MCF-7 cells. (Upper panels) Phase-contrast microscopy shows cell shrinkage, irregularity in shape, and cellular detachment in aurovertin B-treated cells. (Lower panels) MCF-7 cells stained with 4,6-diamidino-2-phenylindole (DAPI).

was used in this study, in which it uses a restraint-based approach that produces reasonable results based on the assumption that the tertiary structures of two proteins will be similar if their sequences are related. Structural bioinformatics which integrates structural biology and bioinformatics is revolutionizing the process of drug discovery. ${ }^{44-46}$ Now, fewer steps are needed to find new drugs: characterization of a protein target, modeling the protein using sequence homology, optimization of the protein structure, and finally docking of small ligands into the active site. Incorporating these features of structural bioinformatics into drug discovery, in silico approaches for identifying potential drug candidates can be virtually screened at a high speed. ${ }^{47,48}$ After thousands of iterating simulations, ligands are able to dock into the optimal binding position and orient properly in the active site of the target protein. ${ }^{48,49}$

Following the assumption that all components of the catalytic core of ATP synthase (F1 sector) are present on the breast cancer cell surface and the complex is capable of synthesizing ATP, could the ligands that inhibit the enzymatic activity of ATP synthase be potential anticancer drugs? We used three ATP synthase inhibitors, aurovertin B, resveratrol, and piceatannol, to treat MCF-7 breast cancer cells in different concentrations and found that the cell densities were reduced. One noteworthy 
observation was that even though aurovertin B showed strong inhibition of the proliferation of multiple breast cancer cell lines, little influence was found on the normal cell MCF-10A. This means that aurovertin B has potent antitumor activities in vitro in breast cancer cell lines without exerting noticeable cytotoxicity toward normal cells.

To investigate the effects induced by aurovertin B treatment, we performed flow cytometry analysis to characterize the changes in DNA content and apoptotic cell death. Our result showed that cell cycle was arrested in G0/G1 phase followed by apoptosis after aurovertin B treatment. These results revealed that treatment of MCF-7 cells with increasing concentrations of aurovertin $\mathrm{B}$ resulted in a dose-dependent accumulation of cells in the G0/G1 phase with a concomitant decrease in cells progressing to the $S$ and G2/M phases. Simultaneously, the accumulation of apoptotic cells in a dosedependent manner was observed in this study as well.

In summary, the combination of proteomics and structural bioinformatics may improve the specificity and efficiency in the design of targeting therapy. Our findings demonstrated that ATP synthase inhibitors can be effective in treating breast cancer cells as ATP synthase is overexpressed on the cell surface of breast cancer. In this study, ATP synthase inhibitor aurovertin B is shown to be able to effectively prevent cell proliferation through apoptotic cell death and cell cycle arrest in G0/G1 phase.

\section{Conclusion}

In this study, we found ATP synthase $\beta$ subunit to be upregulated in tumor tissue. To counteract possible increase in tumor progression brought by this protein upregulation, aurovertin B, a kind of ATP synthase inhibitor, was used to treat MCF-7 breast cancer cells. Our result showed that aurovertin B could serve as a useful new agent to inhibit cell proliferation by cell-cycle arrest in G0/G1 phase and induce apoptotic cell death in MCF-7 cells, while leaving normal cells unharmed. Until now, no investigation has been conducted to explore the possible therapeutic application of ATP synthase inhibitors in breast cancer treatment. Our study provides a new approach to drug discovery which will help speed up the process of novel anticancer drug development and shed light on finding specific target molecules in a variety of biological pathways for cancer therapy.

Acknowledgment. This work was supported by the National Science Council of Taiwan, and NTU Frontier and Innovative Research Projects. We thank Jason Lee for proofreading the manuscript and Dr. Shui-Tein Chen for supporting the 2DE instruments and confocal microscopy.

\section{References}

(1) Smigal, C.; Jemal, A.; Ward, E.; Cokkinides, V.; Smith, R.; Howe, H. L.; Thun, M. Trends in breast cancer by race and ethnicity: update 2006. CA Cancer J. Clin. 2006, 56, 168-183.

(2) Gupta, V.; Harkin, D. P.; Kawakubo, H.; Maheswaran, S. Transforming Growth Factor-beta superfamily: evaluation as breast cancer biomarkers and preventive agents. Curr. Cancer Drug Targets 2004, 4, 165-182.

(3) Seidman, A. D. Systemic treatment of breast cancer. Two decades of progress. Oncology (Williston Park) 2006, 20, 983-990, discussion 99-82, 99-88.

(4) Hsieh, A. C.; Moasser, M. M. Targeting HER proteins in cancer therapy and the role of the non-target HER3. Br. J. Cancer 2007, 97, 453-457.

(5) Wang, X. F.; Birringer, M.; Dong, L. F.; Veprek, P.; Low, P.; Swettenham, E.; Stantic, M.; Yuan, L. H.; Zobalova, R.; Wu, K.;
Ledvina, M.; Ralph, S. J.; Neuzil, J. A peptide conjugate of vitamin E succinate targets breast cancer cells with high ErbB2 expression. Cancer Res. 2007, 67, 3337-3344.

(6) Fernandez Madrid, F. Autoantibodies in breast cancer sera: candidate biomarkers and reporters of tumorigenesis. Cancer Lett. 2005, 230, 187-198.

(7) Duffy, M. J. Predictive markers in breast and other cancers: a review. Clin. Chem. 2005, 51, 494-503.

(8) Gross, J. M.; Yee, D. How does the estrogen receptor work. Breast Cancer Res. 2002, 4, 62-64.

(9) Cui, X.; Schiff, R.; Arpino, G.; Osborne, C. K.; Lee, A. V. Biology of progesterone receptor loss in breast cancer and its implications for endocrine therapy. J. Clin. Oncol. 2005, 23, 7721-7735.

(10) Castiglioni, F.; Terenziani, M.; Carcangiu, M. L.; Miliano, R.; Aiello, P.; Bertola, L.; Triulzi, T.; Gasparini, P.; Camerini, T.; Sozzi, G.; Fossati-Bellani, F.; Menard, S.; Tagliabue, E. Radiation effects on development of HER2-positive breast carcinomas. Clin. Cancer Res. 2007, 13, 46-51.

(11) Prowell, T. M.; Armstrong, D. K. Selecting endocrine therapy for breast cancer: what role does HER-2/neu status play. Semin. Oncol. 2006, 33, 681-687.

(12) Griffiths, D. E.; Houghton, R. L. Studies on energy-linked reactions: modified mitochondrial ATPase of oligomycin-resistant mutants of Saccharomyces cerevisiae. Eur. J. Biochem. 1974, 46, 157-167.

(13) Haslam, J. M.; Proudlock, J. W.; Linnane, A. W. Biogenesis of mitochondria. 20. The effects of altered membrane lipid composition on mitochondrial oxidative phosphorylation in Saccharomyces cerevisiae. J. Bioenerg 1971, 2, 351-370.

(14) Yamamoto, K.; Shimizu, N.; Obi, S.; Kumagaya, S.; Taketani, Y.; Kamiya, A.; Ando, J. Involvement of cell surface ATP synthase in flow-induced ATP release by vascular endothelial cells. Am. J. Physiol. Heart Circ. Physiol. 2007, 293, H1646-1653.

(15) Kenan, D. J.; Wahl, M. L. Ectopic localization of mitochondrial ATP synthase: a target for anti-angiogenesis intervention. J. Bioenerg. Biomembr. 2005, 37, 461-465.

(16) Chi, S. L.; Pizzo, S. V. Angiostatin is directly cytotoxic to tumor cells at low extracellular $\mathrm{pH}$ : a mechanism dependent on cell surface-associated ATP synthase. Cancer Res. 2006, 66, 875-882.

(17) Burrell, H. E.; Wlodarski, B.; Foster, B. J.; Buckley, K. A.; Sharpe, G. R.; Quayle, J. M.; Simpson, A. W.; Gallagher, J. A. Human keratinocytes release ATP and utilize three mechanisms for nucleotide interconversion at the cell surface. J. Biol. Chem. 2005, 280, 29667-29676.

(18) Kim, B. W.; Choo, H. J.; Lee, J. W.; Kim, J. H.; Ko, Y. G. Extracellular ATP is generated by ATP synthase complex in adipocyte lipid rafts. Exp. Mol. Med. 2004, 36, 476-485.

(19) Arakaki, N.; Nagao, T.; Niki, R.; Toyofuku, A.; Tanaka, H.; Kuramoto, Y.; Emoto, Y.; Shibata, H.; Magota, K.; Higuti, T. Possible role of cell surface H+ -ATP synthase in the extracellular ATP synthesis and proliferation of human umbilical vein endothelial cells. Mol. Cancer Res. 2003, 1, 931-939.

(20) Das, B.; Mondragon, M. O.; Sadeghian, M.; Hatcher, V. B.; Norin, A. J. A novel ligand in lymphocyte-mediated cytotoxicity: expression of the beta subunit of $\mathrm{H}+$ transporting ATP synthase on the surface of tumor cell lines. J. Exp. Med. 1994, 180, 273-281.

(21) Martinez, L. O.; Jacquet, S.; Esteve, J. P.; Rolland, C.; Cabezon, E.; Champagne, E.; Pineau, T.; Georgeaud, V.; Walker, J. E.; Terce, F.; Collet, X.; Perret, B.; Barbaras, R. Ectopic beta-chain of ATP synthase is an apolipoprotein A-I receptor in hepatic HDL endocytosis. Nature 2003, 421, 75-79.

(22) Moser, T. L.; Kenan, D. J.; Ashley, T. A.; Roy, J. A.; Goodman, M. D.; Misra, U. K.; Cheek, D. J.; Pizzo, S. V. Endothelial cell surface F1F0 ATP synthase is active in ATP synthesis and is inhibited by Angiostatin. Proc. Natl. Acad. Sci. U.S.A. 2001, 98, 6656-6661.

(23) Chang, S. Y.; Park, S. G.; Kim, S.; Kang, C. Y. Interaction of the C-terminal domain of p43 and the alpha subunit of ATP synthase. Its functional implication in endothelial cell proliferation. J. Biol. Chem. 2002, 277, 8388-8394.

(24) Scotet, E.; Martinez, L. O.; Grant, E.; Barbaras, R.; Jeno, P.; Guiraud, M.; Monsarrat, B.; Saulquin, X.; Maillet, S.; Esteve, J. P.; Lopez, F.; Perret, B.; Collet, X.; Bonneville, M.; Champagne, E. Tumor recognition following Vgamma9Vdelta2 $\mathrm{T}$ cell receptor interactions with a surface F1-ATPase-related structure and apolipoprotein A-I. Immunity 2005, 22, 71-80.

(25) Burwick, N. R.; Wahl, M. L.; Fang, J.; Zhong, Z.; Moser, T. L.; Li, B.; Capaldi, R. A.; Kenan, D. J.; Pizzo, S. V. An Inhibitor of the F1 subunit of ATP synthase (IF1) modulates the activity of Angiostatin on the endothelial cell surface. J. Biol. Chem. 2005, 280, 17401745 . 
(26) Juan, H. F.; Wang, I. H.; Huang, T. C.; Li, J. J.; Chen, S. T.; Huang, H. C. Proteomics analysis of a novel compound: cyclic RGD in breast carcinoma cell line MCF-7. Proteomics 2006, 6, 2991-3000.

(27) Fiser, A.; Sali, A. Modeller: generation and refinement of homologybased protein structure models. Methods Enzymol. 2003, 374, 461491.

(28) Mpamhanga, C. P.; Chen, B.; McLay, I. M.; Ormsby, D. L.; Lindvall, M. K. Retrospective docking study of PDE4B ligands and an analysis of the behavior of selected scoring functions. J. Chem. Inf. Model 2005, 45, 1061-1074.

(29) van Raaij, M. J.; Abrahams, J. P.; Leslie, A. G.; Walker, J. E. The structure of bovine F1-ATPase complexed with the antibiotic inhibitor aurovertin B. Proc. Natl. Acad. Sci. U.S.A. 1996, 93, 69136917.

(30) Venkatachalam, C. M.; Jiang, X.; Oldfield, T.; Waldman, M. LigandFit: a novel method for the shape-directed rapid docking of ligands to protein active sites. J. Mol. Graph. Model 2003, 21, 289-307.

(31) Krammer, A.; Kirchhoff, P. D.; Jiang, X.; Venkatachalam, C. M Waldman, M. LigScore: a novel scoring function for predicting binding affinities. J. Mol. Graph. Model. 2005, 23, 395-407.

(32) Brooks, B. R.; Bruccoleri, R. E.; Olafson, B. D.; States, D. J Swaminathan, S.; Karplus, M. CHARMM: A program for macromolecular energy minimization, and dynamics calculations. J. Comput. Chem. 1983, 4, 187-217.

(33) Huang, T. C.; Huang, H. C.; Chang, C. C.; Chang, H. Y.; Ou, C. H.; Hsu, C. H.; Chen, S. T.; Juan, H. F. An apoptosis-related gene network induced by novel compound-cRGD in human breast cancer cells. FEBS Lett. 2007, 581, 3517-3522.

(34) Camacho-Carvajal, M. M.; Wollscheid, B.; Aebersold, R.; Steimle, V.; Schamel, W. W. Two-dimensional Blue native/SDS gel electrophoresis of multi-protein complexes from whole cellular lysates: a proteomics approach. Mol. Cell Proteomics 2004, 3, 176-182.

(35) Issaq, H. J.; Veenstra, T. D.; Conrads, T. P.; Felschow, D. The SELDITOF MS approach to proteomics: protein profiling and biomarker identification. Biochem. Biophys. Res. Commun. 2002, 292, 587592.

(36) Sethuraman, M.; McComb, M. E.; Huang, H.; Huang, S.; Heibeck, T.; Costello, C. E.; Cohen, R. A. Isotope-coded affinity tag (ICAT) approach to redox proteomics: identification and quantitation of oxidant-sensitive cysteine thiols in complex protein mixtures. $J$. Proteome Res. 2004, 3, 1228-1233.

(37) Yang, Y.; Thannhauser, T. W.; Li, L.; Zhang, S. Development of an integrated approach for evaluation of 2-D gel image analysis:
Impact of multiple proteins in single spots on comparative proteomics in conventional 2-D gel/MALDI workflow. Electrophoresis 2007, 28, 2080-2094.

(38) Bondar, O. P.; Barnidge, D. R.; Klee, E. W.; Davis, B. J.; Klee, G. G. LC-MS/MS quantification of Zn-alpha2 glycoprotein: a potential serum biomarker for prostate cancer. Clin. Chem. 2007, 53, 673678.

(39) Huang, H. L.; Stasyk, T.; Morandell, S.; Dieplinger, H.; Falkensammer, G.; Griesmacher, A.; Mogg, M.; Schreiber, M.; Feuerstein, I.; Huck, C. W.; Stecher, G.; Bonn, G. K.; Huber, L. A. Biomarker discovery in breast cancer serum using 2-D differential gel electrophoresis/ MALDI-TOF/TOF and data validation by routine clinical assays. Electrophoresis 2006, 27, 1641-1650.

(40) Li, H.; Desouza, L. V.; Ghanny, S.; Li, W.; Romaschin, A. D.; Colgan, T. J. O. A.; Siu, K. W. Identification of candidate biomarker proteins released by human endometrial and cervical cancer cells using two-dimensional liquid chromatography/tandem mass spectrometry. J. Proteome Res. 2007, 6, 2615-2622.

(41) Srivastava, S.; Srivastava, R. G. Proteomics in the forefront of cancer biomarker discovery. J. Proteome Res. 2005, 4, 1098-1103.

(42) Zhang, H.; Kong, B.; Qu, X.; Jia, L.; Deng, B.; Yang, Q. Biomarker discovery for ovarian cancer using SELDI-TOF-MS. Gynecol. Oncol. 2006, 102, 61-66.

(43) Lenaz, G. Effect of aurovertin on energy-linked processes related to oxidative phosphorylation. Biochem. Biophys. Res. Commun. 1965, 21, 170-175.

(44) Rognan, D. Chemogenomic approaches to rational drug design. Br. J. Pharmacol. 2007, 152, 38-52.

(45) Chou, K. C. Structural bioinformatics and its impact to biomedical science. Curr. Med. Chem. 2004, 11, 2105-2134.

(46) Scapin, G. Structural biology and drug discovery. Curr. Pharm. Des. 2006, 12, 2087-2097.

(47) Jain, A. N. Virtual screening in lead discovery and optimization. Curr. Opin. Drug Discov. Devel. 2004, 7, 396-403.

(48) Kitchen, D. B.; Decornez, H.; Furr, J. R.; Bajorath, J. Docking and scoring in virtual screening for drug discovery: methods and applications. Nat. Rev. Drug Discov. 2004, 3, 935-949.

(49) Alonso, H.; Bliznyuk, A. A.; Gready, J. E. Combining docking and molecular dynamic simulations in drug design. Med. Res. Rev. 2006, 26, 531-568.

(50) DeLano, W. L. The PyMOL Molecular Graphics System. DeLano Scientific: San Carlos, CA, 2002.

PR700742H 